\title{
Review
}

\section{Herd-level infectious disease surveillance of livestock populations using aggregate samples}

\author{
Marisa L. Rotolo*, Rodger G. Main and Jeffrey J. Zimmerman \\ Veterinary Diagnostic Laboratory, College of Veterinary Medicine, lowa State University, Ames, \\ lowa, USA
}

\author{
Received 8 December 2017; Accepted 5 April 2018; \\ First published online 21 May 2018
}

\begin{abstract}
All sectors of livestock production are in the process of shifting from small populations on many farms to large populations on fewer farms. A concurrent shift has occurred in the number of livestock moved across political boundaries. The unintended consequence of these changes has been the appearance of multifactorial diseases that are resistant to traditional methods of prevention and control. The need to understand complex animal health conditions mandates a shift toward the collection of longitudinal animal health data. Historically, collection of such data has frustrated and challenged animal health specialists. A promising trend in the evolution toward more efficient and effective livestock disease surveillance is the increased use of aggregate samples, e.g. bulk tank milk and oral fluid specimens. These sample types provide the means to monitor disease, estimate herd prevalence, and evaluate spatiotemporal trends in disease distribution. Thus, this article provides an overview of the use of bulk tank milk and penbased oral fluids in the surveillance of livestock populations for infectious diseases.
\end{abstract}

Keywords: Aggregate sample, bulk tank milk, oral fluid, surveillance.

\section{Introduction}

Globally and locally, achieving the control of historically impactful infectious diseases of livestock continues to frustrate producers and challenge animal health specialists. A core requirement of a successful control program is the ongoing collection of disease data from populations. Schwabe (1982) describes this as the process of establishing baseline levels 'against which effects of intervention (control) efforts can be measured'.

The ongoing burden of disease in endemic areas and the expansion of infectious agents into previously free areas expose the frailty of current surveillance and response/control programs (Backer et al., 2009; Lee, 2015; Saeed et al., 2015; Neira et al., 2017). Foot-and-mouth disease virus (FMDV) was identified in 1897, but 116 years later, endemic FMDV losses were estimated at \$6.5-\$21 billion dollars annually and only 66 of the 181 (36.5\%) OIE-member countries are 'FMD free where vaccination is not practiced' (Longjam et al., 2011; Knight-Jones and Rushton,

*Corresponding author: Marisa Rotolo, E-mail: mrotolo@iastate.edu
2013; OIE, 2017a). Classical swine fever virus (CSFV) was identified in 1903 (de Schweinitz, Dorset, 1903), but in 2017, just 32 of the $181(17.7 \%)$ OIE-member countries are considered free of CSFV (OIE, 2017b). This, despite the profound global economic burden of CSFV and the clear benefits of eradication, e.g. the benefit:cost ratio of CSFV eradication in the USA was estimated at $\geq 13.2$ (USDA, 1981; Pinto et al., 2011). Initially identified on the basis of outbreaks of unknown origin in the 1980s, porcine reproductive and respiratory syndrome virus (PRRSV) was isolated in 1991 and has become endemic in most major pork-producing regions of the world (Wensvoort et al., 1991; Zimmerman et al., 2012). Holtkamp et al. (2013) estimated the US pork producers' losses to PRRSV at \$664 million annually. Nathues et al. (2017) estimated losses to European producers at $€ 126.79$ per sow per year and $€ 3.77$ per pig marketed in herds with 'slight' PRRS.

A promising trend in the evolution toward more efficient and effective livestock disease surveillance is the increased use of aggregate samples (Thurmond and Perez, 2006; Strutzberg-Minder et al., 2015; Gibert et al., 2017; Rotolo, et al., 2017). By definition, an aggregate sample represents two or more animals at a specific location and time, e.g. bulk tank milk and pen-based oral fluid samples. 
Table 1. Pathogens detected in bulk tank milk

\begin{tabular}{|c|c|}
\hline Method & Reference \\
\hline \multicolumn{2}{|l|}{ Nucleic acid detection } \\
\hline Border disease virus & Berriatua et al. (2006) \\
\hline Bovine viral diarrhea virus & $\begin{array}{l}\text { Drew et al. (1999); Houe (1999); Kramps et al. (1999); Lanyon et al. (2014); Radwan et al. } \\
\text { (1995); Renshaw et al. (2000) }\end{array}$ \\
\hline Coxiella burnetti & Astobiza et al. (2012); Muskens et al. (2011); Rodolakis et al. (2007) \\
\hline Foot-and-mouth disease virus & Reid et al. (2006); Thurmond and Perez (2006) \\
\hline $\begin{array}{l}\text { Mycobacterium avium } \\
\text { subspecies paratuberculosis }\end{array}$ & $\begin{array}{l}\text { Cousins et al. (1999); Jayaro et al. (2004); Slana et al. (2008); } \\
\text { Tasara et al. (2005) }\end{array}$ \\
\hline Mycoplasma bovis & Arcangioli et al. (2011); Justice-Allen et al. (2011); Maunsell et al. (2011) \\
\hline Staphylococcus aureus & Haran et al. (2012); Zanardi et al. (2014) \\
\hline Streptococcus agalactiae & Phuektes et al. (2003); Soltau et al. (2017) \\
\hline \multicolumn{2}{|l|}{ Antibody detection } \\
\hline Border disease virus & Berriatua et al. (2006); Corbiere et al. (2012); Garcia-Perez et al. (2010) \\
\hline Bovine viral diarrhea virus & $\begin{array}{l}\text { Foddai et al. (2015); Houe (1999); Hanon et al. (2017); Kramps et al. (1999); Lanyon et al. } \\
\text { (2014); Renshaw et al. (2000) }\end{array}$ \\
\hline C. burnetti & Muskens et al. (2011); van den Brom et al. (2012) \\
\hline Foot-and-mouth disease virus & Armstrong et al. (1997a, 1997b); Armstrong, Mathew (2001) \\
\hline $\begin{array}{l}\text { M. avium subspecies } \\
\text { paratuberculosis }\end{array}$ & $\begin{array}{l}\text { Beaver et al. (2016); Nielsen et al. (2000); van Weering et al. (2007); } \\
\text { Wilson et al. (2010) }\end{array}$ \\
\hline M. bovis & Nielsen et al. (2015) \\
\hline Schmallenberg virus & $\begin{array}{l}\text { Balmer et al. (2014); Collins et al. (2017); Daly et al. (2015); } \\
\text { Johnson et al. (2014) }\end{array}$ \\
\hline \multicolumn{2}{|l|}{ Culture or isolation } \\
\hline $\begin{array}{l}\text { M. avium subspecies } \\
\text { paratuberculosis }\end{array}$ & Slana et al. (2008) \\
\hline M. bovis & Justice-Allen et al. (2011); Maunsell et al. (2011); Parker et al. (2017a,b) \\
\hline S. aureus & Olde Riekerink et al. (2006, 2010) \\
\hline S. agalactiae & Keefe (1997) \\
\hline
\end{tabular}

As opposed to individual animal samples, e.g. probang samples, swabs, or blood samples, aggregate samples can be collected without animal restraint. The use of aggregate samples in veterinary surveillance has grown in tandem with developments in diagnostic technology, e.g. nucleic acid-based assays and antibody assays specifically adapted to these specimens. The purpose of this article is to review the use of bulk tank milk and pen-based oral fluids in infectious disease surveillance of livestock populations.

\section{Bulk tank milk samples}

Bulk tanks are designed to cool, agitate, and store milk in bovine, ovine, and caprine grade A dairies. Among other requirements of the Pasteurized Milk Ordinance (U.S. Food and Drug Administration, 2015), bulk tanks must chill milk $\left(4.4-7^{\circ} \mathrm{C}\right)$ within $2 \mathrm{~h}$ of collection and maintain this range thereafter. The size and number of bulk tanks vary among farms as a function of the number of animals in the herd or flock, but larger operations may have multiple tanks capable of storing thousands of gallons of milk. Milk haulers may collect once a day, more than once a day, or every other day, depending on the farm's storage capacity and milk production levels. Regardless of the collection schedule, bulk tanks must be emptied, cleaned, and sanitized at least every $72 \mathrm{~h}$ (Bickett-Weddle et al., 2011; U.S. Food and Drug Administration, 2015).

In the context of disease surveillance, samples from bulk milk tanks represent the lactating cows in the herd (Sekiya et al., 2013).
Depending on the governmental standards or ordinances, tanks are agitated for $\geq 10$ min after which samples are collected aseptically from the top of the tank using a sterile pipette, syringe, or sanitized dipper (Bickett-Weddle et al., 2011; U.S. Food and Drug Administration, 2015). Although bulk tank milk samples do not represent dry cows or cows on milk withhold, they provide an economical, convenient, and timely approach for the detection of specific pathogens and/or estimation of herd prevalence (Olde Riekerink et al., 2006; Sekiya et al., 2013; Lanyon et al., 2014; Collins et al., 2017). Economically significant pathogens detectable in bulk tank milk samples and reported in the refereed literature are discussed below and listed in Table 1.

\section{Schmallenberg virus}

Schmallenberg virus (SBV) is an arthropod vector-borne orthobunyavirus first detected in dairy herds in Germany and the Netherlands in 2011 (Balmer et al., 2014; Gubbins et al., 2014; Johnson et al., 2014; Daly et al., 2015). SBV infection causes abortions, congenital malformations, diarrhea, and fever in bovine, ovine, and caprine species (Johnson et al., 2014; Daly et al., 2015; Collins et al., 2017). The duration of SBV viremia is relatively short, i.e. an average of 3-4 days (Gubbins et al., 2014), but SBV serum-neutralizing antibodies can be detected in cattle for as long as 24 months post-infection (Elbers et al., 2014). The detection of SBV nucleic acid has not been reported 
in milk, but antibodies to SBV can be detected in an individual cow and bulk tank milk samples using commercial indirect enzyme-linked immunosorbent assay (ELISAs) (Balmer et al., 2014; Johnson et al., 2014; Daly et al., 2015). Although test performance estimates are not available (diagnostic sensitivity, diagnostic specificity), results of bulk tank milk ELISA testing were predictive of within-herd seroprevalence and herd immunity (Collins et al., 2017). Analyses based on bulk tank milk testing results have been used to assess the spatial distribution, rate of spread, direction of the spread, and effect of farm altitude on the prevalence of SBV (Balmer et al., 2014; Johnson et al., 2014).

\section{Bovine viral diarrhea virus}

First described in the 1940s, bovine viral diarrhea virus (BVDV) is a pestivirus transmitted through direct contact or fetal (in utero) infection (Goens, 2002). Clinical signs of BVDV include watery and/or bloody diarrhea, dehydration, pyrexia, tenesmus, tachypnea, and ulcers of the muzzle, lips, oral cavity, and/or nares (Goens, 2002).

BVDV antibodies can be detected in bulk tank milk samples using blocking, indirect, or competitive ELISAs (Houe, 1999; Kramps et al., 1999; Renshaw et al., 2000; Lanyon et al., 2014; Foddai et al., 2015; Hanon et al., 2017). A Danish blocking ELISA demonstrated a diagnostic sensitivity of $100 \%$ and diagnostic specificity of $62 \%$ when testing bulk tank milk samples from herds with a BVDV prevalence of $26 \%$ (Foddai et al., 2015). Diagnostic sensitivities and specificities of competitive ELISAs were reported as $97-100 \%$ and $99 \%$, respectively; whereas the diagnostic sensitivities and specificities of indirect ELISAs were reported as $94-100 \%$ and $98 \%$ (Hanon et al., 2017). As with SBV, bulk tank milk ELISA results were highly associated with herd seroprevalence (Lanyon et al., 2014).

Persistently infected (PI) animals, the result of fetal infection during the first trimester of pregnancy (immunotolerance), serve as a continuous source of infection (Houe, 1999; Fray et al., 2000; Renshaw et al., 2000). PI cows produce little-to-no BVD antibody, but continuously shed real-time reverse transcription polymerase chain reaction (RT-rtPCR)-detectable levels of BVDV in milk (Radwan et al., 1995; Kramps et al., 1999; Houe, 1999; Renshaw et al., 2000). Drew et al. (1999) reported 100\% diagnostic sensitivity and specificity for PCR-based detection of BVDV RNA in bulk tank milk samples from herds with PI cows.

Strategically, antibody detection is used to identify the herds with circulating BVDV, and nucleic acid detection is used to identify the herds with PI cattle (Lanyon et al., 2014). Monitoring changes in antibody prevalence has been used to determine whether a BVDV infection is ongoing or recent (Lanyon et al., 2014). ELISA testing has also been used to monitor declining antibody levels after removal of PI cattle (Houe, 1999).

\section{Border disease virus}

First reported in England and Wales in 1958 and closely related to BVDV, border disease virus (BDV) is a pestivirus of ovine and caprine species (Nettleton et al., 1998). BDV is transmitted through direct contact or transplacentally, with infection during early pregnancy resulting in PI offspring (Garcia-Perez et al., 2010). Goats are susceptible to BDV, but infection is rare and typically results in abortion (Nettleton et al., 1998). In sheep, clinical signs of BDV include abortion, stillbirths, and nonviable lambs.

As in the case of BVDV, PI animals shed BDV continuously and do not produce antibodies. Bulk tank milk samples can be tested for BDV by RT-rtPCR; however, estimates of diagnostic performance have not been reported (Berriatua et al., 2006). Immunocompetent animals produce antibodies detectable in bulk tank milk (Garcia-Perez et al., 2010). In one study, the diagnostic sensitivity and specificity of a blocking ELISA for BDV detection in bulk tank milk samples was reported as 100 and $85.2 \%$, respectively (Corbiere et al., 2012). A high seroprevalence of BDV in lactating animals suggests the presence of PI animals (Berriatua et al., 2006). Thus, ELISA testing of bulk tank milk samples provides the means to estimate the prevalence of BDV in flocks and may indirectly reveal the presence of PI animals (Berriatua et al., 2006; Garcia-Perez et al., 2010).

\section{Foot-and-mouth disease virus}

FMDV is a highly impactful picornavirus of cloven-hoofed animals (Reid et al., 2006; Thurmond and Perez, 2006; Knight-Jones and Rushton, 2013). FMDV can be transmitted by direct or indirect contact (Bravo de Rueda et al., 2014). Clinical signs of FMDV infection include vesicular lesions, decrease in milk yield in lactating cattle, and pyrexia (Armstrong and Mathew, 2001).

FMDV was detected in milk samples from individual cows by RT-rtPCR for 23 days post-inoculation (Reid et al., 2006). Estimates of the diagnostic sensitivity and specificity of RT-rtPCR for the detection of FMDV in bulk tank milk samples has not been reported, but Thurmond and Perez (2006) predicted that RT-rtPCR testing of bulk tank milk samples would detect FMDV 4-7 days earlier than detection based on the recognition/reporting of clinical signs.

FMDV antibodies may be detected in ovine and bovine milk using blocking ELISAs (Armstrong, 1997a, 1997b). Estimates for diagnostic sensitivity and specificity of these ELISAs are not available, but Armstrong and Mathew found a statistically significant correlation $(r=0.53)$ between serum and milk antibody titers (Armstrong and Mathew, 2001). On this basis, these researchers suggested that antibody testing of bulk tank milk samples would be an effective approach for monitoring herd immunity and/or evaluating population susceptibility to FMDV.

\section{Mycobacterium avium subspecies paratuberculosis}

Mycobacterium avium subspecies paratuberculosis (MAP) is the etiologic agent of Johne's disease in ruminants (Mortier et al., 2014). Most commonly acquired via fecal-oral transmission, Johne's disease is characterized by enteritis, decreased milk yield, weight 
loss, diarrhea, and death (Wilson et al., 2010; Mortier et al., 2014). A causal role for MAP in Crohn's disease has been postulated, but was neither confirmed nor rejected by an assessment of the available data (Feller et al., 2007).

MAP is detectable in milk via culture and PCR testing, but culture of bulk tank milk samples is not practical because the procedure is neither diagnostically sensitive nor timely, i.e. culture can take 18-52 weeks (Slana et al., 2008). The most common target of PCR assays is multiple copy insertion sequence IS900 in the MAP genome (Slana et al., 2008). The analytical sensitivity of the IS900 PCR is reported as 5-6 MAP cells $\mathrm{ml}^{-1}$ of bulk tank milk versus 83 MAP cells $\mathrm{ml}^{-1}$ for a PCR targeting F57. However, IS900 PCRs may have issues with analytical specificity because of the homology of this region across mycobacteria species (Cousins et al., 1999; Tasara et al., 2005; Slana et al., 2008). Jayaro et al. (2004) reported a diagnostic sensitivity of $21 \%$ and diagnostic specificity of $50 \%$ for bulk tank milk samples using an IS900 PCR. No estimates of diagnostic sensitivity and specificity are available for F57-based PCRs.

ELISA-detectable MAP antibodies are present in bulk tank milk samples, but interpretation of testing results has not been clearly established (Nielsen et al., 2000; van Weering et al., 2007; Wilson et al., 2010; Beaver et al., 2016). Regardless, some researchers believe that ELISA testing of bulk tank milk samples can be used effectively by monitoring changes over time (van Weering et al., 2007; Beaver et al., 2016). Alternatively, Beaver et al. (2016), suggested the concurrent use of both assays for bulk tank milk monitoring programs for MAP (Beaver et al., 2016). Thus, herds with positive PCR results and high ELISA titers reflected active infection; whereas, herds with positive PCR results but low ELISA titers reflected environmental contamination (Beaver et al., 2016).

\section{Coxiella burnetii ( $Q$ fever)}

Coxiella burnetii is an obligate, intracellular rickettsial organism and the cause of $\mathrm{Q}$ fever in animals and humans (Kim et al., 2005). Infection with C. burnetii results in reproductive disease, including metritis and infertility in cattle and abortion in goats and sheep (Kim et al., 2005; Rodolakis et al., 2007). Shedding patterns of $C$. burnetii in milk is species-dependent and varies among cattle, sheep, and goats (Rodolakis et al., 2007). Cattle shed C. burnetii in milk for several months, goats shed for a shorter time, and sheep do not reliably shed in milk (Rodolakis et al., 2007; Astobiza et al., 2012). Antibody to and nucleic acids of $C$. burnetii are detectable in bulk tank milk samples with ELISA and PCR, respectively (Rodolakis et al., 2007; van den Brom et al., 2012). Muskens et al. (2011) reported diagnostic sensitivity and specificity of 82 and $70 \%$, respectively, when testing bulk tank milk samples by a commercial real-time PCR. The diagnostic sensitivity and specificity of a commercial C. burnetii antibody ELISA for bulk tank milk was reported as 88.2 and $94.6 \%$, respectively, using manufacturer-recommended cutoffs (van den Brom et al., 2012). When used in combination, ELISA testing of bulk tank milk samples can be used to determine herd exposure and estimate prevalence of $C$. burnetii, while
PCR testing can be used to determine shedding and prevalence (Muskens et al., 2011; Astobiza et al., 2012).

\section{Detection of bacterial pathogens associated with mastitis}

Streptococcus agalactiae is a highly contagious, obligate pathogen of the bovine mammary gland and a cause of subclinical and clinical mastitis (Keefe, 1997; Phuektes et al., 2003; Olde Riekerink et al., 2006; Mweu et al., 2012). Streptococcus agalactiae may be detected in bulk tank milk samples by culture or PCR (Keefe, 1997; Phuektes et al., 2003). As reviewed by Phuektes et al. (2003), estimates of the diagnostic sensitivity of culture range from 20 to $84 \%$. Estimates of the diagnostic sensitivity and specificity are not available, but as would be expected, testing multiple bulk tank milk samples was shown to increase the likelihood of detecting $S$. agalactiae by PCR (Phuektes et al., 2003; Soltau et al., 2017). ELISA-detectable S. agalactiae antibodies have been reported in individual milk samples, but this approach has not been evaluated for bulk tank milk testing (Logan et al., 1982).

Staphylococcus aureus is an opportunistic pathogen and a cause of subclinical and clinical mastitis in cattle, sheep, and goats (Olde Riekerink et al., 2006; Haran et al., 2012; Zanardi et al., 2014; Merz et al., 2016). As reviewed by Olde Riekerink et al. (2010), culture of bulk tank milk for $S$. aureus had an estimated diagnostic sensitivity of $21-42 \%$ and a diagnostic specificity of $100 \%$. Repeated sampling is recognized to improve the probability of detection by culture (Olde Riekerink et al., 2006, 2010). PCR testing of bulk tank milk samples can be used to detect $S$. aureus, estimate herd prevalence of the infection, and assess for the presence of methicillin-resistant strains (Haran et al., 2012). The diagnostic sensitivity and specificity of PCR testing for $S$. aureus in bulk tank milk samples is reported at 99 and 67\%, respectively (Zanardi et al., 2014). Using individual milk, ELISA testing for antibodies against $S$. aureus may be used to as a screening tool to detect infected animals (Fox and Adams, 2000).

Mycoplasma bovis is a highly pathogenic mycoplasma causing both mastitis and respiratory disease in adult cattle (Parker et al., 2017a). Mycoplasma bovis is detectable in bulk tank milk samples by culture, but the assay can take 7-10 days and overgrowth of bacteria is problematic (Parker et al., 2017a, 2017b). The diagnostic sensitivity of $M$. bovis culture is reported as $50 \%$, with diagnostic specificity estimates as high as $100 \%$ (Justice-Allen et al., 2011; Maunsell et al., 2011). The diagnostic sensitivity and specificity of $M$. bovis PCR for individual milk samples is reportedly 100 and $99.3 \%$, respectively, but estimates of PCR performance for bulk tank milk samples have not been reported (Cai et al., 2005). PCR testing allows for more rapid detection of $M$. bovis versus culture and herd prevalence estimates can be extrapolated from the results (Arcangioli et al., 2011). A commercial antibody ELISA is available for bulk tank milk testing, and estimates for diagnostic sensitivity and specificity are 60.4 and $97.3 \%$, respectively (Nielsen et al., 2015). The combination of PCR and ELISA testing can reveal 
M. bovis infection in a herd and is an effective approach for surveillance (Nielsen et al., 2015).

\section{Oral fluid samples}

Oral fluids are collected from swine or cattle by providing access to a rope suspended in the pen, then recovering the sample for diagnostic testing (Smith et al., 2004; Prickett et al., 2008a, 2008b; Stanford et al., 2009; Prickett et al., 2010). Oral fluid samples are an aggregate sample composed of saliva and transudate originating from capillaries within the buccal and gingival mucosa (Prickett et al., 2008a). Oral fluids contain both local and serumderived antibodies and pathogens (Prickett et al., 2008a, 2008b; Prickett and Zimmerman, 2010). In addition, viruses, bacteria, and other test analytes in feed, water, or the environment may be present in oral fluids as a result of normal exploratory behavior (Kittawornrat and Zimmerman, 2011; Johnson et al., 2012). This explains the detection of porcine epidemic diarrhea virus (PEDV) in swine oral fluid samples and Escherichia coli and salmonella in cattle (Smith et al., 2005a, 2005b; Renter et al., 2008; Bjustrom-Kraft et al., 2016). In cattle, oral fluids have been used in the observational studies in feedlot cattle (Renter et al., 2008; Smith et al., 2005a, 2005b), but have not been routinely utilized in surveillance. In contrast, oral fluids have been used extensively for disease surveillance in swine populations. Therefore, the remainder of this section will focus exclusively on this subject.

Oral fluids can be collected from groups or individual pigs (White et al., 2014; Pepin et al., 2015a, 2015b). In group-housed animals, oral fluids offer a higher probability of detection with fewer samples when compared with individual serum samples (Olsen et al., 2013). Sampling guidelines for oral fluid collection at the barn or site level have been published (Rotolo et al., 2017).

Diagnostic assays optimized for swine oral fluid specimens have been available in North American veterinary diagnostic laboratories since 2010 (Olsen et al., 2013; Bjustrom-Kraft et al., 2018). In three North American swine-interest veterinary diagnostic laboratories, the number of oral fluid tests performed increased from 20,963 in 2010 to 369,439 in 2016 (Bjustrom-Kraft et al., 2018). Pathogens detectable in oral fluid samples and reported in the refereed literature are listed in Table 2. Selected pathogens are reviewed below.

\section{Foot-and-mouth-disease virus}

Rapid screening of swine herds is critical in the control of FMDV because pigs aerosolize a large amount of virus compared with cattle and promulgate virus transmission (Stenfeldt et al., 2016). Under experimental conditions, FMDV was isolated from swine oral fluids on day post-inoculation (DPI) 15 (Senthilkumaran et al., 2017). By RT-rtPCR, FMDV was detected from one DPI, i.e. prior to the appearance of clinical signs, and up to 21 DPI (Mouchantat et al., 2014; Senthilkumaran et al., 2017). RNA was detected in oral fluids one day earlier than oral or nasal swab samples and continued $\sim 7$ days longer (Senthilkumaran et al., 2017). A field-deployable reverse transcription-insulated isothermal PCR has also been used to detect FMDV RNA in oral fluids (Ambagala et al., 2016). FMDV antigens were detected in oral fluids 1-6 DPI using lateral flow immunochromatographic strip tests and 2-3 DPI using a double-antibody sandwich ELISA (Senthilkumaran et al., 2017). FMDV IgA was detected in oral fluids using a solid-phase competitive ELISA beginning at 14 DPI (Senthilkumaran et al., 2017). Pacheco et al. (2010) were not successful in detecting FMDV IgM or IgG in oral fluid samples. Estimates of diagnostic sensitivity and specificity have not been reported for the assays reported in this paragraph. Although FMDV oral fluid assay development is in its early stages, preliminary results support the use of nucleic acid and antibody detection as a method to rapidly screen herds (Ambagala et al., 2016; Senthilkumaran et al., 2017).

\section{Classical swine fever virus}

CSFV is a pestivirus with significant economic consequences resulting from clinical disease, lost export markets, and costs related to control and eradication efforts (Fernández-Carrión et al., 2016). CSFV can be transmitted by direct or indirect contact and, depending on the virulence of the strain, causes pyrexia, anorexia, lethargy, conjunctivitis, enlarged and discolored lymph nodes, constipation, and diarrhea in affected pigs (Moennig et al., 2003; Petrini et al., 2017). Under experimental settings, CSFV was detected in oral fluids by RT-rtPCR from seven up to $30 \mathrm{DPI}$, with a higher detection rate in oral fluid than blood samples (40 vs 28\%) (Dietze et al., 2017; Petrini et al., 2017). Estimates of diagnostic sensitivity and specificity have not been reported for these assays and, overall, research on CSFV oral fluid diagnostics is in its initial phases.

\section{African swine fever virus}

Infection with African swine fever virus (ASFV), the only member of family Asfarviridae, is a cause of fever, hemorrhage, and mortality in domestic and feral pigs (Sanchez-Vizcaino and Neira, 2012; Guinat et al., 2014; Gimenez-Lirola et al., 2016). Transmitted through direct and indirect contact, ASFV is of particular concern because, since its introduction into the Democratic Republic of Georgia in 2007, it has steadily advanced westwardly into Europe via feral swine and threatens to spread eastwardly into China (Guinat et al., 2014; Vergne et al., 2017).

Under experimental conditions, ASFV was detected in oral fluid 3-5 DPI by PCR (Guinat et al., 2014; Grau et al., 2015). ASFV antibodies were detected at 11 DPI in individual oral fluid samples by indirect ELISA under experimental conditions (Mur et al., 2013). The pattern of antibody response in oral fluids was similar to the pattern seen in serum (Mur et al., 2013). ASFV antibodies were also detected using a p30-based indirect ELISA in oral fluids (Gimenez-Lirola et al., 2016). Diagnostic sensitivities and specificities for these assays have not been reported. As in the cases of FMDV and CSFV, further studies are needed 
Table 2. Pathogens detected in oral fluid

\begin{tabular}{|c|c|}
\hline Method & Reference \\
\hline \multicolumn{2}{|l|}{ Nucleic acid detection } \\
\hline African swine fever virus & Grau et al. (2015); Guinat et al. (2014) \\
\hline Classical swine fever virus & Dietze et al. (2017); Petrini et al. (2017) \\
\hline Foot-and-mouth disease & Ambagala et al. (2016); Mouchantat et al. (2014); Senthilkumaran et al. (2017) \\
\hline Influenza A virus & Allerson et al. (2014); Decorte et al. (2015); Goodell et al. (2013); Romagosa et al. (2012) \\
\hline Porcine deltacoronavirus & Homwong et al. (2016); Sinha et al. (2015) \\
\hline Porcine epidemic diarrhea virus & Bjustrom-Kraft et al. (2016) \\
\hline $\begin{array}{l}\text { Porcine reproductive and } \\
\text { respiratory syndrome virus }\end{array}$ & $\begin{array}{l}\text { Biernacka et al. (2016); Kittawornrat et al. (2010, 2014); Pepin et al. (2015a, 2015b); } \\
\text { Prickett et al. (2008a, 2008b); Olsen et al. (2013); Ramirez et al. (2012); } \\
\text { Rotolo et al. (2017) }\end{array}$ \\
\hline \multicolumn{2}{|l|}{ Antigen detection } \\
\hline Foot-and-mouth disease & Senthilkumaran et al. (2017) \\
\hline \multicolumn{2}{|l|}{ Antibody detection } \\
\hline African swine fever virus & Gimenez-Lirola et al. (2016); Mur et al. (2013) \\
\hline Influenza A virus & Panyasing et al. (2013, 2014b); Strutzberg-Minder et al. (2015) \\
\hline Porcine epidemic diarrhea virus & Bjustrom-Kraft et al. (2016) \\
\hline $\begin{array}{l}\text { Porcine reproductive and } \\
\text { respiratory syndrome virus }\end{array}$ & Kittawornrat et al. (2013); Langenhorst et al. (2012) \\
\hline \multicolumn{2}{|l|}{ Culture or isolation } \\
\hline Influenza A virus & Goodell et al. (2013) \\
\hline
\end{tabular}

to optimize ASFV oral fluid assays and assess their use in the field (Grau et al., 2015).

\section{Porcine reproductive and respiratory syndrome virus}

PRRSV is an arterivirus transmitted through direct and indirect contact (Zimmerman et al., 2012). Clinical signs of PRRSV vary based on the age of the pig and the virulence of the isolate. In sows, clinical signs include abortion, stillbirths, anorexia, and mortality (Zimmerman et al., 2012). PRRSV is often an etiological component of the porcine respiratory disease complex in growing pigs (Zimmerman et al., 2012).

The detection of PRRSV nucleic acid in oral fluids has been extensively documented under field and experimental conditions (Prickett et al., 2008a, 2008b; Kittawornrat et al., 2010, 2014; Ramirez et al., 2012; Pepin et al., 2015a, 2015b; Rotolo et al., 2017). Kittawornrat et al. (2010) reported detection in $\sim 10 \%$ of experimentally inoculated boars at $24 \mathrm{~h}$ post-inoculation by RT-rtPCR. Olsen et al. (2013) evaluated test performance as a function of within-pen prevalence. In pens holding 25 pigs, the probability of detecting PRRSV RNA or PRRSV antibody in pens containing $\geq 1$ positive ( $4 \%$ prevalence) was 62 and $61 \%$, respectively. PRRSV may also be sequenced from oral fluids (Biernacka et al., 2016).

$\operatorname{IgG}, \operatorname{IgA}$, and $\operatorname{IgM}$ antibody isotypes were detected in oral fluids collected from individual boars using a commercial PRRS serum antibody indirect ELISA modified for oral fluids (Kittawornat et al., 2013). The pattern of PRRSV antibody ontogeny was similar in serum and oral fluid, with IgM detected in oral fluids at three DPI, IgA at seven DPI, and IgG at eight DPI (Kittawornrat et al., 2013). Commercial PRRSV oral fluid ELISAs have since become available. Antibodies were also detected in oral fluid using a fluorescent microsphere immunoassay with a reported diagnostic sensitivity of $92 \%$ and diagnostic specificity of $91 \%$ (Langenhorst $e t$ al., 2012).

Testing of oral fluids can be used to assess the effectiveness of PRRSV control and elimination programs (Biernacka et al., 2016; Rotolo et al., 2017). A distinct advantage of PRRSV oral fluid-based surveillance is that pen-based oral fluid sampling provides a higher probability of detection than individual animal sampling using either RT-rtPCR or ELISA (Olsen et al., 2013).

\section{Influenza $A$ virus}

Influenza A virus (IAV) is an orthomyxovirus of human beings, horses, sea mammals, birds, and pigs, transmitted via direct and indirect contact (Hughes et al., 2015; Neira et al., 2016). IAV in commercial swine herds results in chronic, endemic infection with respiratory or reproductive clinical signs, as well as clinically inapparent infections (Goodell et al., 2013; Panyasing et al., 2013). IAV is an important pathogen to surveil in pigs because of its zoonotic potential (Vincent et al., 2014; Hughes et al., 2015).

Under experimental conditions, IAV RNA was detected in swine oral fluids by one DPI and up to 69 DPI (Allerson et al., 2014; Decorte et al., 2015). Decorte et al. (2015) reported the duration of detection in oral fluids as 14 days longer than detection in nasal swabs by RT-rtPCR (Decorte et al., 2015). Compared with individual nasal swabs, the diagnostic sensitivity and specificity of pen-based oral fluid RT-rtPCR testing was estimated at 80 and $100 \%$, respectively (Romagosa et al., 2012). Although further optimization is necessary, IAV has also been isolated from oral fluids (Goodell et al., 2013). Sequencing of IAV from oral fluids has been reported (Panyasing et al., 2014a). RT-rtPCR testing of oral fluids can 
be used to track viral circulation and to monitor the effect of vaccination and control programs in commercial swine herds (Goodell et al., 2013).

Panyasing et al. (2013) reported the ontogeny of IAV IgM, $\operatorname{Ig} \mathrm{A}$, and $\operatorname{IgG}$ in pigs housed under experimental conditions, using isotype-specific indirect ELISAs. Serum and oral fluid IgG responses were highly correlated $(r=0.80)$ (Panyasing et al., 2013). Detection of IAV antibody has also been reported using blocking or competitive ELISA formats (Panyasing et al., 2014b; Strutzberg-Minder et al., 2015). Diagnostic sensitivity and specificity estimates have not been established for these assays. Antibody detection in oral fluids allows for the detection of IAV infection in the absence of clinical signs (Panyasing et al., 2013).

\section{Coronaviruses}

PEDV is an enteric coronavirus transmitted via the fecal-oral route (Crawford et al., 2015; Bjustrom-Kraft et al., 2016). Clinical signs of PEDV infection in swine include watery diarrhea, vomiting, and mortality in neonates (Bjustrom-Kraft et al., 2016). In the field, Bjustrom-Kraft et al. (2016) reported the detection of PEDV nucleic acid in oral fluids from 6 days post-exposure (DPE) to 69 DPE. PEDV was detected 15 days longer in oral fluid samples compared with pen fecal samples, and, compared with individual rectal swabs, oral fluids demonstrated a higher concentration of detectable virus and higher rate of detection. In the same study, Bjustrom-Kraft et al. (2016) reported the detection of PEDV antibody (gG and $\operatorname{IgA}$ ) by $13 \mathrm{DPE}$ in oral fluids. The diagnostic sensitivity and specificity of a PEDV IgG oral fluid ELISA was reported as 69 and $97 \%$, respectively. In contrast, the diagnostic sensitivity and specificity of a PEDV IgA oral fluid ELISA were reported as 100 and 100\%, respectively (Bjustrom-Kraft et al., 2016). Although estimates of diagnostic sensitivity and specificity have not been reported, the oral fluid RT-rtPCR is an effective tool to monitor for PEDV presence in herds, and IgA antibody testing offers an effective method to evaluate herd-level immunity (Bjustrom-Kraft et al., 2016).

Like PEDV, porcine deltacoronavirus (PDCoV) is an enteric coronavirus that causes diarrhea and vomiting in pigs (Homwong et al., 2016). PDCoV can be detected in oral fluids by RT-rtPCR, although estimates of diagnostic sensitivity and specificity are not available (Sinha et al., 2015; Homwong et al., 2016; Zhang, 2016). Homwong et al. (2016) reported that the detection of $\mathrm{PDCoV}$ nucleic acid in oral fluids was 1.89 times more likely than detection in feces. PDCoV antibody ontogeny in serum and oral fluids has not yet been reported.

\section{Discussion}

Globally, the production of livestock - poultry, cattle, and swine - is in the process of shifting from small populations on many farms to large populations on fewer farms (Hoban et al., 1997; Marquer, 2010; Barkema et al., 2015; Gale, 2017). Readily accessible USDA data from the dairy and swine industries highlight this trend. In 1982, $\sim 275,000$ US dairy farms housed $\sim 11,000,000$ dairy cows. By 2012, the number of dairy farms dropped to $\sim 64,000$, while animal numbers remained relatively stable at $\sim 9,250,000$ (USDA, 2014). Pork production has followed the same trend. In 1982, 330,000 US farms housed $\sim 55,000,000$ pigs in 1982. By 2012, the number of farms with pigs declined to $\sim 63,000$, while the number of pigs increased to $\sim 66,000,000$ (USDA, 2014). Increases in herd size are important to disease control because herd immunity becomes more difficult to achieve as population increases, which in turn leads to pathogen endemicity (LeBlanc et al., 2006; Pitzer et al., 2016).

Over the same time period, a shift occurred in the movement of livestock across political boundaries. In 1960, 13,500,000 live cattle crossed US state lines for feeding or breeding purposes (Hennessy et al., 2005). By 2015, this number had risen to 20,500,000 (USDA, 2017). Similarly, $2,500,000$ pigs were moved across US stateliness in 1960, in contrast to 52,500,000 moved in 2016 (Shields and Mathews, 2003; USDA, 2017). Similar patterns have emerged in Europe. For example, Denmark, France, Germany, Italy, the Netherlands, Poland, and Spain cumulatively imported $~ 910,000$ live pigs and exported $\sim 937,000$ live pigs in 1961 (FAO, 2017). In contrast, these countries imported $\sim 22,000,000$ live pigs and exported $\sim 27,000,000$ in 2013 (FAO, 2017). Trends in livestock movement are important because of the well-established role of animal transport in the spread of disease, e.g. the 2001 FMDV outbreak in the UK and, more recently, spread of PEDV throughout the Western Hemisphere (Davies, 2015; Guinat et al., 2016).

The unintended consequences of changes in the structure and management of livestock populations have manifested themselves in the appearance of multifactorial diseases resistant to traditional methods of prevention and control, e.g. bovine and porcine respiratory disease complexes (Schwabe, 1982; Gardner et al., 2002; Hagglund et al., 2006; LeBlanc et al., 2006; Bochev, 2007; Edwards, 2010; Pitzer et al., 2016). The need to understand complex animal health conditions mandates a shift toward the collection of longitudinal animal health data. New intervention strategies or unanticipated events, e.g. the introduction of an exotic pathogen, can then be evaluated in the context of their impact on baseline values.

Cumulatively, peer-reviewed research supports the conclusion that aggregate samples offer the opportunity to expand the scope of applied surveillance. Testing of bulk tank milk samples provides bovine and small ruminant practitioners and producers the means to monitor disease and estimate herd prevalence and provides animal health researchers the means to evaluate the spatial distribution and rate of disease transmission (Berriatua et al., 2006; Garcia-Perez et al., 2010; Balmer et al., 2014; Johnson et al., 2014; Collins et al., 2017). Swine oral fluids offer a more analytically sensitive detection system than individual pig samples, and at a lower cost (Goodell et al., 2013; Olsen et al., 2013). Continued progress toward the goal of effective surveillance using aggregate sampling requires research in two areas: (1) continued development and adaption of diagnostic technology for the most globally impactful diseases of animals and human beings (zoonoses); (2) continued development of 
statistically valid sampling guidelines including probability of detection estimates by sample size, sampling allocation, and frequency of sampling for farm and regional surveillance.

\section{References}

Allerson MW, Davies PR, Gramer MR and Torremorell M (2014). Infection dynamics of pandemic $2009 \mathrm{H} 1 \mathrm{~N} 1$ influenza virus in a two-site swine herd. Transboundary and Emerging Diseases 61: 490-499.

Ambagala A, Fisher M, Goolia M, Nfon C, Furukawa-Stoffer T, Ortega Polo R and Lung O (2016). Field-deployable reverse transcription-insulated isothermal PCR (RT-iiPCR) assay for rapid and sensitive detection of foot-and-mouth disease virus. Transboundary Emerging Diseases 64: 1610-1623.

Arcangioli MA, Chazel M, Sellal E, Botrel MA, Bezille P, Poumarat F, Calavas D and Le Grand D (2011). Prevalence of Mycoplasma bovis udder infection in dairy cattle: preliminary field investigation in southeast France. New Zealand Veterinary Journal 59: 75-78.

Armstrong RM (1997a). The detection of antibodies against foot-and-mouth disease virus in sheep milk. Journal of Virological Methods 69: 45-51.

Armstrong RM (1997b). Development of tests for antibodies against foot-and-mouth disease virus in cattle milk. Journal of Virological Methods 63: 175-180.

Armstrong RM and Mathew ES (2001). Predicting herd protection against foot-and-mouth disease by testing individual and bulk tank milk samples. Journal of Virological Methods 97: 87-99.

Astobiza I, Ruiz-Fons F, Pinero A, Barandika JF, Hurtado A and Garcia-Perez AL (2012). Estimation of Coxiella burnetii prevalence in dairy cattle in intensive systems by serological and molecular analyses of bulk-tank milk samples. Journal of Dairy Science 95: 1632-1638.

Backer JA, Hagenaars TJ, van Roermund HJ and de Jong MCM (2009). Modelling the effectiveness and risks of vaccination strategies to control classical swine fever epidemics. Journal of the Royal Society Interface 6: 849-861.

Balmer S, Vogtlin A, Thur B, Buchi M, Abril C, Houmard M, Danuser $J$ and Schwermer H (2014). Serosurveillance of Schmallenberg virus in Switzerland using bulk tank milk samples. Preventive Veterinary Medicine 116: 370-379.

Barkema HW, von Keyserlingk MAG, Kastelic JP, Lam TJGM, Luby C, Roy JP, LeBlanc SJ, Keefe GP and Kelton DF (2015). Invited review: changes in the dairy industry affecting dairy cattle health and welfare. Journal of Dairy Science 98: 1-20.

Beaver A, Cazer CL, Ruegg PL, Grohn YT and Schukken YH (2016). Implications of PCR and ELISA results on the routes of bulk-tank contamination with Mycobacterium avium ssp. paratuberculosis. Journal of Dairy Science 99: 1391-1405.

Berriatua E, Barandika JF, Aduriz G, Hurtado A, Estevez L, Atxaerandio R, and Garcia-Perez AL (2006). Flock-prevalence of border disease virus infection in Basque dairy-sheep estimated by bulk-tank milk analysis. Veterinary Microbiology 118: 37-46.

Bickett-Weddle D, Keplinger M and Sanchez H (2011). Dairy Industry Manual, USDA APHIS Foreign Animal Disease Preparedness and Response Plan. http://www.cfsph.iastate.edu/pdf/dairy-industrymanual.

Biernacka K, Karbowiak P, Wróbel P, Charęza T, Czopowicz M, Balka G, Goodell C, Rauh R and Stadejek T (2016). Detection of porcine reproductive and respiratory syndrome virus (PRRSV) and influenza A virus (IAV) in oral fluid of pigs. Research in Veterinary Science 109: 74-80.

Bjustrom-Kraft J, Woodard K, Gimenez-Lirola L, Rotolo M, Wang C, Sun Y, Lasley P, Zhang J, Baum D, Gauger P, Main R and Zimmerman J (2016). Porcine epidemic diarrhea virus (PEDV) detection and antibody response in commercial growing pigs. BMC Veterinary Research 12: 99.

Bjustrom-Kraft J, Christopher-Hennings J, Daly R, Main R, Torrison J and Zimmerman $\mathrm{J}$ (2018). A review of the development and use of oral fluid diagnostics in swine medicine. Journal of Swine Health and Production (in press).

Bochev I (2007). Porcine respiratory disease complex (PRDC): a review. I. Etiology, epidemiology, clinical forms and pathoanatomical features. Bulgarian Journal of Veterinary Medicine 10: 131-146.

Bravo de Rueda C, Dekker A, Eble PL and de Jong MC (2014). Identification of factors associated with increased excretion of foot-and-mouth disease virus. Preventive Veterinary Medicine 113: 23-33.

Cai HY, Bell-Rodgers P, Parker L and Prescott JF (2005). Development of a real-time PCR for detection of Mycoplasma bovis in bovine milk and lung samples. Journal of Veterinary Diagnostic Investigation 17: $537-545$.

Collins AB, Grant J, Barrett D, Doherty ML, Hallinan A and Mee JF (2017). Schmallenberg virus: predicting within-herd seroprevalence using bulk-tank milk antibody titres and exploring individual animal antibody titres using empirical distribution functions (EDF). Preventive Veterinary Medicine 143: 68-78.

Corbiere F, Puget C, Bernardin E, Brugidou R and Schelcher F (2012). Short communication: performance of a blocking antibody ELISA bulk-tank milk test for detection of dairy sheep flocks exposed to border disease virus. Journal of Dairy Science 95: 6542-6545.

Cousins DV, Whittington R, Marsh I, Masters A, Evans RJ and Kluver P (1999). Mycobacteria distinct from Mycobacterium avium subsp. paratuberculosis isolated from the faeces of ruminants possess IS900-like sequences detectable by IS900 polymerase chain reaction: implications for diagnosis. Molecular and Cellular Probes 14: 431-442.

Crawford K, Lager K, Miller L, Opriessnig T, Gerber P, and Hesse R (2015). Evaluation of porcine epidemic diarrhea virus transmission and the immune response in growing pigs. Veterinary Research 46: 49.

Daly JM, King B, Tarlinton RA, Gough KC, Maddison BC and Blowey $R$ (2015). Comparison of Schmallenberg virus antibody levels detected in milk and serum from individual cows. BMC Veterinary Research 11: 56.

Davies PR (2015). The dilemma of rare events: porcine epidemic diarrhea virus in North America. Preventive Veterinary Medicine 122: 235-241.

Decorte I, Steensels M, Lambrecht B, Cay AB and De Regge N (2015). Detection and isolation of swine influenza A virus in spiked oral fluid and samples from individually housed, experimentally infected pigs: potential role of porcine oral fluid in active influenza A virus surveillance in swine. PLOS ONE 10: e0139586.

de Schweinitz EA and Dorset M (1903). A form of hog cholera not caused by the hog-cholera bacillus. U.S. Bureau of Animal Industry Circular No. 41.

Dietze K, Tucakov A, Engel T, Wirtz S, Depner K, Globig A, Kammerer R and Mouchantat S (2017). Rope-based oral fluid sampling for early detection of classical swine fever in domestic pigs at group level. BMC Veterinary Research 13: 5.

Drew TW, Yapp F and Paton DJ (1999). The detection of bovine viral diarrhoea virus in bulk milk samples by the use of a single-tube RT-PCR. Veterinary Microbiology 64: 145-154.

Edwards TA (2010). Control methods for bovine respiratory disease for feedlot cattle. The veterinary clinics of North America. Food Animal Practice 26: 273-284.

Elbers ARW, Stockhofe-Zurwieden N and van der Poel WHM (2014). Schmallenberg virus antibody persistence in adult cattle after natural infection and decay of maternal antibodies in calves. $B M C$ Veterinary Research 10: 103.

FAO (2017). FAOSTAT Statistics Database. Food and Agriculture Organization of the United Nations. http://www.fao.org/faostat/ en/\#data/TA (Accessed 31 October 2017). 
Feller M, Huwiler K, Stephan R, Altpeter E, Shang A, Furrer H, Pfyffer GE, Jemmi T, Baumgartner A and Egger M (2007). Mycobacterium avium subspecies paratuberculosis and Crohn's disease: a systematic review and meta-analysis. The Lancet. Infectious Diseases 7: 607-613.

Fernández-Carrión E, Ivorra B, Martínez-López B, Ramos AM and Sánchez-Vizcaíno JM (2016). Implementation and validation of an economic module in the Be-FAST model to predict costs generated by livestock disease epidemics: application to classical Swine fever epidemics in Spain. Preventive Veterinary Medicine 126: 66-73.

Foddai A, Enøe C, Stockmarr A, Krogh K and Uttenthal A (2015). Challenges for bovine viral diarrhoea virus antibody detection in bulk milk by antibody enzyme-linked immunosorbent assays due to changes in milk production levels. Acta Veterinaria Scandinavica 57: 32 .

Fox LK and Adams DS (2000). The ability of the enzyme-linked immunosorbent assay to detect antibody against Staphylococcus aureus in milk following experimental intramammary infection. Journal of Veterinary Medicine B, Infectious Disease and Veterinary Public Health 47: 517-526.

Fray MD, Paton DJ and Alenius S (2000). The effects of bovine viral diarrhoea virus on cattle reproduction in relation to disease control. Animal Reproduction Science 60-61: 615-627.

Gale F (2017). China's Pork Imports Rise Along with Production Costs. United States Department of Agriculture.

Garcia-Perez AL, Ruiz-Fons F, Barandika JF, Aduriz G, Juste RA and Hurtado A (2010). Border disease virus seroprevalence correlates to antibodies in bulk-tank milk and reproductive performance of dairy sheep flocks. Journal of Dairy Science 93: 2444-2449.

Gardner IA, Willeberg P and Mousing J (2002). Empirical and theoretical evidence for herd size as a risk factor for swine diseases. Animal Health Research Reviews 3: 43-55.

Gibert E, Martin-Valls G and Mateu E (2017). Comparisons of protocols for the analysis of type 1 porcine reproductive and respiratory syndrome virus by RT-PCR using oral fluids. Journal of Virological Methods 243: 190-195.

Giménez-Lirola LG, Mur L, Rivera B, Mogler M, Sun Y, Lizano S, Goodell C, Harris DL, Rowland RR, Gallardo C, Sánchez-Vizcaíno JM and Zimmerman J (2016). Detection of African swine fever virus antibodies in serum and oral fluid specimens using a recombinant protein 30 (p30) dual matrix indirect ELISA. PLOS ONE 11: e0161230.

Goens SD (2002). The evolution of bovine viral diarrhea: a review. The Canadian Veterinary Journal 43: 946-954.

Goodell CK, Prickett J, Kittawornrat A, Zhou F, Rauh R, Nelson W, O'Connell C, Burrell A, Wang C, Yoon KJ and Zimmerman JJ (2013). Probability of detecting influenza A virus subtypes $\mathrm{H} 1 \mathrm{~N} 1$ and $\mathrm{H} 3 \mathrm{~N} 2$ in individual pig nasal swabs and pen-based oral fluid specimens over time. Veterinary Microbiology 166: 450460.

Grau FR, Schroeder ME, Mulhern EL, McIntosh MT and Bounpheng MA (2015). Detection of African swine fever, classical swine fever, and foot-and-mouth disease viruses in swine oral fluids by multiplex reverse transcription real-time polymerase chain reaction. Journal of Veterinary Diagnostic Investigation 27: 140-149.

Gubbins S, Turner J, Baylis M, van der Stede Y, van Schaik G, Cortinas Abrahantes J and Wilson AJ (2014). Inferences about the transmission of Schmallenberg virus within and between farms. Preventive Veterinary Medicine 116: 380-390.

Guinat C, Reis AL, Netheron CL, Goatley L, Pfeiffer DU and Dixon L (2014). Dynamics of African swine fever virus shedding and excretion in domestic pigs infected by intramuscular inoculation and contact transmission. Veterinary Research 45: 93.

Guinat C, Relun A, Wall B, Morris A, Dixon L and Pfeiffer DU (2016). Exploring pig trade patterns to inform the design of risk-based disease surveillance and control strategies. Scientific Reports 6: 28429.

Hagglund S, Svensson C, Emanuelson U, Valarcher JF and Alenius S (2006). Dynamics of virus infections involved in the bovine respiratory complex in Swedish dairy herds. The Veterinary Journal 172: $320-328$.

Hanon JB, De Baere M, De la Ferte C, Roelandt S, Van der Stede Y and Cay B (2017). Evaluation of 16 commercial antibody ELISAs for the detection of bovine viral diarrhea virus-specific antibodies in serum and milk using well-characterized sample panels. Journal of Veterinary Diagnostic Investigation 29: 833-843.

Haran KP, Godden SM, Boxrud D, Jawahir S, Bender JB and Sreevatsan S (2012). Prevalence and characterization of Staphylococcus aureus, including methicillin-resistant Staphylococcus aureus, isolated from bulk tank milk from Minnesota dairy farms. Journal of Clinical Microbiology 50: 688-695.

Hennessy DA, Roosen J and Jensen HH (2005). Infectious disease, productivity, and scale in open and closed animal production systems. American Journal of Agriculture Economics 87: 900-917.

Hoban TJ, McMillan M, Molnar J and Parrish JD (1997). Industrialization of poultry and swine production: implications for natural resource management. Journal of Soil and Water Conservation 52: 406-409.

Holtkamp DJ, Kliebenstein JB, Neumann EJ, Zimmerman JJ, Rotto $\mathrm{HF}$, Yoder TK, Wang C, Yeske PE, Mowrer CL and Haley $\mathrm{CH}$ (2013). Assessment of the economic impact of porcine reproductive and respiratory syndrome virus on United States pork producers. Journal of Swine Health and Production 21: 72-84.

Homwong N, Jarvis MC, Ching Lam H, Diaz A, Rovira A, Nelson M and Marthaler D (2016). Characterization and evolution of porcine deltacoronavirus in the United States. Preventive Veterinary Medicine 123: $168-174$.

Houe H (1999). Epidemiological features and economical importance of bovine virus diarrhoea virus (BVDV) infections. Veterinary Microbiology 64: 89-107.

Hughes HR, Vincent AL, Brockmeier SL, Gauger PC, Pena L, Santos J, Braucher DR, Perez DR and Loving CL (2015). Oral fluids as a live-animal sample source for evaluating cross-reactivity and crossprotection following intranasal influenza A virus vaccination in pigs. Clinical and Vaccine Immunology 22: 1109-1120.

Jayaro BM, Pillai SR, Wolfgang DR, Griswold DR, Rossiter CA, Tewari D, Burns CM and Hutchinson LJ (2004). Evaluation of IS900-PCR assay for detection of Mycobacterium avium subspecies Paratuberculosis infection in cattle using quarter milk and bulk tank milk samples. Foodborne Pathogens and Disease 1: 17-26.

Johnson A, Bradshaw B, Boland C and Ross P (2014). A bulk milk tank study to detect evidence of spread of Schmallenberg virus infection in the south-west of Ireland in 2013. Irish Veterinary Journal 67: 11 .

Johnson JK, Main RM and Zimmerman JJ (2012). Exogenous source of PRRSV antibody in positive oral-fluid ELISA results. Journal of Swine Health and Production 20: 215.

Justice-Allen A, Trujillo J, Goodell G and Wilson D (2011). Detection of multiple Mycoplasma species in bulk tank milk samples using real-time PCR and conventional culture and comparison of test sensitivities. Journal of Dairy Science 94: 3411-3419.

Keefe GP (1997). Streptococcus agalactiae mastitis: a review. The Canadian Veterinary Journal 38: 429-437.

Kim SG, Kim EH, Lafferty CJ and Dubovi E (2005). Coxiella burnetii in bulk tank milk samples, United States. Emerging Infectious Diseases 11: 619-621.

Kittawornrat A and Zimmerman JJ (2011). Toward a better understanding of pig behavior and pig welfare. Animal Health Research Reviews 12: 25-32.

Kittawornrat A, Prickett J, Chittick W, Wang C, Engel M, Johnson J, Patnayak D, Schwartz T, Whitney D, Olsen C, Schwartz K, and Zimmerman J (2010). Porcine reproductive and respiratory syndrome virus (PRRSV) in serum and oral fluid samples from individual boars: Will oral fluid replace serum for PRRSV surveillance? Virus Research 154: 170-176.

Kittawornrat A, Engle M, Panyasing Y, Olsen C, Schwartz K, Rice A, Lizano S, Wang C and Zimmerman J (2013). Kinetics of the 
porcine reproductive and respiratory syndrome virus (PRRSV) humoral immune response in swine serum and oral fluids collected from individual boars. BMC Veterinary Research 9: 61

Kittawornrat A, Panyasing Y, Goodell C, Wang C, Gauger P, Harmon K, Rauh R, Desfresne L, Levis I and Zimmerman J (2014). Porcine reproductive and respiratory syndrome virus (PRRSV) surveillance using pre-weaning oral fluid samples detects circulation of wild-type PRRSV. Veterinary Microbiology 168: $331-339$.

Knight-Jones TJD and Rushton J (2013). The economic impacts of foot and mouth disease-what are they, how big are they and where do they occur? Preventive Veterinary Medicine 112: 161-173.

Kramps JA, van Maanen C, van de Wetering G, Stienstra G, Quak S, Brinkhof J, Rùnsholt L and Nylin B (1999). A simple, rapid and reliable enzyme-linked immunosorbent assay for the detection of bovine virus diarrhoea virus (BVDV) specific antibodies in cattle serum, plasma and bulk milk. Veterinary Microbiology 64: 135-144.

Langenhorst RJ, Lawson S, Kittawornrat A, Zimmerman JJ, Sun Z, Li Y, Christopher-Hennings J, Nelson EA and Fang Y (2012). Development of a fluorescent microsphere immunoassay for detection of antibodies against porcine reproductive and respiratory syndrome virus using oral fluid samples as an alternative to serum-based assays. Clinical and Vaccine Immunology 19: 180-189.

Lanyon SR, McCoy R, Bergman E and Reichel MP (2014). Milk as a diagnostic sample for a commercially available ELISA to identify bovine viral diarrhoea (BVD) antibodies in dairy herds. Australian Veterinary Journal 92: 269-273.

LeBlanc SJ, Lissemore KD, Kelton DF, Duffield TF and Leslie KE (2006). Major advances in disease prevention in dairy cattle. Journal of Dairy Science 89: 1267-1279.

Lee C (2015). Porcine epidemic diarrhea virus: an emerging and re-emerging epizootic swine virus. Virology Journal 12: 193.

Logan EF, Meneely DJ and Mackie DP (1982). Enzyme-linked immunosorbent assay for Streptococcus agalactiae antibodies in bovine milk. Veterinary Record 110: 247-249.

Longjam N, Deb R, Sarmah AK, Tayo T, Awachat VB and Saxena VK (2011). A brief review on diagnosis of foot-and-mouth disease of livestock: conventional to molecular tools. Veterinary Medicine International 2011: 905768.

Marquer P (2010). Pig farming in the EU, a changing sector. Eurostat: Statistics in focus 8 .

Maunsell FP, Woolums AR, Francoz D, Rosenbusch RF, Step DL, Wilson DJ and Janzen ED (2011). Mycoplasma bovis infections in cattle. Journal of Veterinary Internal Medicine 25: 772-783.

Merz A, Stephan R and Johler S (2016). Staphylococcus aureus isolates from goat and sheep milk seem to be closely related and differ from isolates detected from bovine milk. Frontiers in Microbiology 7: 319.

Moennig V, Floegel-Niesmann G and Greiser-Wilke I (2003). Clinical signs and epidemiology of classical swine fever: a review of new knowledge. The Veterinary Journal 165: 11-20.

Mortier RA, Barkema HW, Negron ME, Orsel K, Wolf R and De Buck J (2014). Antibody response early after experimental infection with Mycobacterium avium subspecies paratuberculosis in dairy calves. Journal of Dairy Science 97: 5558-5565.

Mouchantat S, Haas B, Bohle W, Globig A, Lange E, Mettenleiter TC and Depner K (2014). Proof of principle: non-invasive sampling for early detection of foot-and-mouth disease virus infection in wild boar using a rope-in-a-bait sampling technique. Veterinary Microbiology 172: 329-333.

Mur L, Gallardo C, Soler A, Zimmerman J, Pelayo V, Nieto R, Sanchez-Vizcaino JM and Arias M (2013). Potential use of oral fluid samples for serological diagnosis of African swine fever. Veterinary Microbiology 165: 135-139.

Muskens J, van Engelen E, van Maanen C, Bartels C and Lam TJ (2011). Prevalence of Coxiella burnetii infection in Dutch dairy herds based on testing bulk tank milk and individual samples by PCR and ELISA. Veterinary Record 168: 79.
Mweu MM, Nielsen SS, Halasa T and Toft N (2012). Annual incidence, prevalence and transmission characteristics of Streptococcus agalactiae in Danish dairy herds. Preventive Veterinary Medicine 106: 244-250.

Nathues H, Alarcon P, Rushton J, Jolie R, Fiebig K, Jimenez M, Geurts V and Nathues C (2017). Cost of porcine reproductive and respiratory syndrome virus at individual farm level-an economic disease model. Preventive Veterinary Medicine 142: 16-29.

Neira V, Rabinowitz P, Rendahl A, Paccha B, Gibbs SG and Torremorell M (2016). Characterization of viral load, viability and persistence of influenza A virus in air and on surfaces of swine production facilities. PLOS ONE 11: e0146616.

Neira V, Brito B, Mena J, Culhane M, Apel MI, Max V, Perez P, Moreno V, Mathieu C, Johow M, Badia C, Torremorell M, Medina R and Ortega R (2017). Epidemiological investigations of the introduction of porcine reproductive and respiratory syndrome virus in Chile, 2013-2015. PLoS ONE 12: e0181569.

Nettleton PF, Gilray JA, Russo P and Dlissi E (1998). Border disease of sheep and goats. Veterinary Research 29: 327-340.

Nielsen PK, Petersen MB, Nielsen LR, Halasa T, and Toft N (2015). Latent class analysis of bulk tank milk PCR and ELISA testing for herd level diagnosis of Mycoplasma bovis. Preventive Veterinary Medicine 121: 338-342.

Nielsen SS, Thamsborg SM, Houe H and Bitsch V (2000). Bulk-tank milk ELISA antibodies for estimating the prevalence of paratuberculosis in Danish dairy herds. Preventive Veterinary Medicine 44: 1-7.

OIE (2017a). List of FMD Free Members. World Organization for Animal Health. http://www.oie.int/animal-health-in-the-world/officialdisease-status/fmd/list-of-fmd-free-members/\#c156. (Accessed 3 October 2017).

OIE (2017b). List of CSF free Member Countries. http://www.oie.int/ animal-health-in-the-world/official-disease-status/classical-swinefever/list-of-csf-free-member-countries/. (Accessed 3 October 2017).

Olde Riekerink RGM, Barkema HW, Veenstra S, Poole DE, Dingwell RT and Keefe GP (2006). Prevalence of contagious mastitis pathogens in bulk tank milk in Prince Edward Island. The Canadian Veterinary Journal 47: 567-572.

Olde Riekerink RGM, Barkema HW, Scholl DT, Poole DE and Kelton DF (2010). Short communication: comparing real-time PCR and bacteriological cultures for Streptococcus agalactiae and Staphylococcus aureus in bulk-tank milk samples. Preventive Veterinary Medicine 97: 20-28.

Olsen C, Wang C, Christopher-Hennings J, Doolittle K, Harmon KM, Abate S, Kittawornrat A, Lizano S, Main R, Nelson EA, Otterson $\mathrm{T}$, Panyasing $\mathrm{Y}$, Rademacher $\mathrm{C}$, Rauh R, Shah R and Zimmerman J (2013). Probability of detecting porcine reproductive and respiratory syndrome virus infection using pen-based swine oral fluid specimens as a function of within-pen prevalence. Journal of Veterinary Diagnostic Investigation 25: 328-335.

Pacheco JM, Butler JE, Jew J, Ferman GS, Zhu J and Golde WT (2010). Iga antibody response of swine to foot-and-mouth disease virus infection and vaccination. Clinical and V accine Immunology 17: $550-558$.

Panyasing Y, Goodell CK, Giménez-Lirola L, Kittawornrat A, Wang C, Schwartz KJ and Zimmerman JJ (2013). Kinetics of influenza A virus nucleoprotein antibody (IgM, IgA, and $\operatorname{IgG})$ in serum and oral fluid specimens from pigs infected under experimental conditions. Vaccine 31: 6210-6215.

Panyasing Y, Goodell C, Kittawornwat A, Wang C, Levis I, Desfresne L, Rauh R, Gauger PC, Zhang J, Lin X, Azeem S, Ghorbani-Nezami S, Yoon KJ and Zimmerman JJ (2014a). Influenza A virus surveillance based on pre-weaning piglet oral fluid samples. Transboundary and Emerging Diseases 63: 328-338.

Panyasing Y, Goodell CK, Wang C, Kittawornrat A, Prickett JR, Schwartz KJ, Ballagi A, Lizano S and Zimmerman JJ (2014b). Detection of influenza A virus nucleoprotein antibodies in oral fluid specimens from pigs infected under experimental conditions 
using a blocking ELISA. Transboundary and Emerging Diseases 61: $177-184$.

Parker AM, House JK, Hazelton MS, Bosward KL and Sheehy PA (2017a). Comparison of culture and a multiplex probe PCR for identifying Mycoplasma species in bovine milk, semen and swab samples. PLOS ONE 12: e0173422.

Parker AM, House JK, Hazelton MS, Bosward KL, Morton JM and Sheehy PA (2017b). Bulk tank milk antibody ELISA as a biosecurity tool for detecting dairy herds with past exposure to Mycoplasma bovis. Journal of Dairy Science 100: 8296-8309.

Pepin BJ, Kittawornrat A, Liu F, Gauger PC, Harmon K, Abate S, Main R, Carton C, Hargrove J, Rademacher C, Ramirez A and Zimmerman J (2015a). Comparison of specimens for detection of porcine reproductive and respiratory syndrome virus infection in boar studs. Transboundary and Emerging Diseases 62: 295-304.

Pepin BJ, Liu F, Main R, Ramirez A and Zimmerman J (2015b). Comparison of specimens for detection of porcine reproductive and respiratory syndrome virus infection in boar studs. Journal of Swine Health and Production 23: 35-37.

Petrini S, Pierini I, Giammarioli M, Feliziani F and De Mia GM (2017). Detection of classical swine fever virus infection by individual oral fluid of pigs following experimental inoculation. Journal of Veterinary Diagnostic Investigation 29: 254-257.

Phuektes P, Browning GF, Anderson G and Mansell PD (2003). Multiplex polymerase chain reaction as a mastitis screening test for Staphylococcus aureus, Streptococcus agalactiae, Streptococcus dysgalactiae and Streptococcus uberis in bulk milk samples. Journal of Dairy Research 70: 149-155.

Pinto J, Depner K and Vargas-Teran M (2011). Overview of classical swine fever: learning from regional disease control strategies. EMPRES Transboundary Animal Disease Bulletin No. 39: 46-51.

Pitzer VE, Aguas R, Riley S, Loeffen WLA, Wood JLN and Grenfell BT (2016). High turnover drives prolonged persistence of influenza in managed pig herds. Journal of the Royal Society Interface 13: 20160138.

Prickett JR and Zimmerman JJ (2010). The development of oral fluidbased diagnostics and applications in veterinary medicine. Animal Health Research Reviews 11: 207-216.

Prickett JR, Kim W, Simer R, Yoon KJ and Zimmerman JJ (2008a). Oral-fluid samples for surveillance of commercial growing pigs for porcine reproductive and respiratory syndrome virus and porcine circovirus type 2 infections. Journal of Swine Health and Production 16: 86-91.

Prickett JR, Simer R, Christopher-Hennings J, Yoon KJ, Evans RB and Zimmerman JJ (2008b). Detection of porcine reproductive and respiratory syndrome virus infection in porcine oral fluid samples: a longitudinal study under experimental conditions. Journal of Veterinary Diagnostic Investigation 20: 156-163.

Prickett JR, Cutler S, Kinyon JM, Naberhaus N, Stensland WR, Yoon KJ and Zimmerman JJ (2010). Stability of porcine reproductive and respiratory syndrome virus and antibody in swine oral fluid. Journal of Swine Health and Production 18: 187-195.

Radwan GS, Brock KV, Hogan JS and Smith KL (1995). Development of a PCR amplification assay as a screening test using bulk milk samples for identifying dairy herds infected with bovine viral diarrhea virus. Veterinary Microbiology 44: 77-92.

Ramirez A, Wang C, Prickett JR, Pogranichniy R, Yoon KJ, Main R, Johnson JK, Rademacher C, Hoogland M, Hoffmann P, Kurtz A, Kurtz E and Zimmerman J (2012). Efficient surveillance of pig populations using oral fluids. Preventive Veterinary Medicine 104: 292-300.

Reid SM, Parida S, King DP, Hutchings GH, Shaw AE, Ferris NP, Zhang Z, Hillerton JE and Paton DJ (2006). Utility of automated real-time RT-PCR for the detection of foot-and-mouth disease virus excreted in milk. Veterinary Research 37: 121-132.

Renshaw RW, Ray R and Dubovi EJ (2000). Comparison of virus isolation and reverse transcription polymerase chain reaction assay for detection of bovine viral diarrhea virus in bulk milk tank samples. Journal of Veterinary Diagnostic Investigation 12: 184-186.

Renter DG, Smith DR, King R, Stilborn R, Berg J, Berezowski J and McFall M (2008). Detection and determinants of Escherichia coli O157:H7 in Alberta feedlot pens immediately prior to slaughter. Canadian Journal of Veterinary Research 72: 217-227.

Rodolakis A, Berri M, Hechard C, Caudron C, Souriau A, Bodier CC, Blanchard B, Camuset P, Devillechaise P, Natorp JC, Vadet JP and Arricau-Bouvery N (2007). Comparison of Coxiella burnetii shedding in milk of dairy bovine, caprine, and ovine herds. Journal of Dairy Science 90: 5352-5360.

Romagosa A, Gramer M, Joo HS and Torremorell M (2012). Sensitivity of oral fluids for detecting influenza A virus in populations of vaccinated and non-vaccinated pigs. Influenza and Other Respiratory Viruses 6: 110-118.

Rotolo ML, Sun Y, Wang C, Gimenez-Lirola L, Baum DH, Gauger PC, Harmon KM, Hoogland M, Main R and Zimmerman JJ (2017). Sampling guidelines for oral fluid-based surveys of group-housed animals. Veterinary Microbiology 209: 20-29.

Saeed A, Kanwal S, Arshad M, Ali M, Shaikh RS and Abubaka M (2015). Foot-and-mouth disease: overview of motives of disease spread and efficacy of available vaccines. Journal of Animal Science and Technology 57: 10.

Sanchez-Vizcaino JM and Neira MA (2012). African swine fever virus. In: Zimmerman JJ, Karriker LA, Ramirez A, Schwartz KJ, and Stevenson GW (eds) Diseases of Swine, 10th edn. Ames: Wiley and Sons, pp. 396-404.

Schwabe C (1982). The current epidemiological revolution in veterinary medicine. Part I. Preventive Veterinary Medicine 1: 5-15.

Sekiya M, Zintl A and Doherty M (2013). Bulk milk ELISA and the diagnosis of parasite infections in dairy herds: a review. Irish Veterinary Journal 66: 14.

Senthilkumaran C, Yang M, Bittner H, Ambagala A, Lung O, Zimmerman J, Gimenez-Lirola LG and Nfon C (2017). Detection of genome, antigen, and antibodies in oral fluids from pigs infected with foot-and-mouth disease virus. The Canadian Journal of Veterinary Research 81: 82-90.

Shields DA and Mathews KH Jr (2003). Interstate livestock movements, LDP-M-108-01. United States Department of Agriculture, Economic Research Service.

Sinha A, Gauger P, Zhang J, Yoon KJ and Harmon K (2015). PCR-based retrospective evaluation of diagnostic samples for emergence of porcine deltacoronavirus in US swine. Veterinary Microbiology 179: 296-298.

Slana I, Kralik P, Kralova A and Pavlik I (2008). On-farm spread of Mycobacterium avium subsp. paratuberculosis in raw milk studied by IS900 and F57 competitive real time quantitative PCR and culture examination. International Journal of Food Microbiology 128: 250-257.

Smith DR, Gray JT, Moxley RA, Younts-Dahl SM, Blackford MP, Hinkley S, Hungerford LL, Milton CT and Klopfenstein TJ (2004). A diagnostic strategy to determine the Shiga toxinproducing Eschericbia coli $\mathrm{O} 157$ status of pens of feedlot cattle. Epidemiology and Infection 132: 297-302.

Smith DR, Moxley RA, Clowser SL, Folmer JD, Hinkley S, Erickson GE and Klopfenstein TJ (2005a). Use of rope devices to describe and explain the feedlot ecology of Salmonella by time and place. Foodborne Pathogens and Disease 2: 61-69.

Smith DR, Moxley RA, Clowser SL, Folmer JD, Hinkley S, Erickson GE and Klopfenstein TJ (2005b). Use of rope devices to describe and explain the feedlot ecology of Escherichia coli $\mathrm{O} 157: \mathrm{H} 7$ by time and place. Foodborne Pathogens and Disease 2: 50-60.

Soltau JB, Einax E, Klengel K, Katholm J, Failing K, Wehrend A and Donat K (2017). Within-herd prevalence thresholds for herd-level detection of mastitis pathogens using multiplex real-time PCR in bulk tank milk samples. Journal of Dairy Science 100: 8287-8295.

Stanford K, Silasi R, McAllister TA and Schwartzkopf-Genswein KS (2009). Behavior of feedlot cattle affects voluntary oral and 
physical interactions with manila ropes. Journal of Animal Science 87: 296-303.

Stenfeldt C, Diaz-San Segundo F, de los Santos T, Rodriguez LL and Arzt J (2016). The pathogenesis of foot-and-mouth disease in pigs. Frontiers in Veterinary Science 3: 41.

Strutzberg-Minder K, Boehmer J, Fischer S, Homuth M, Gomez-Duren O, Finger G and Genzow M (2015). Monitoring influenza $A$ virus infection in pigs by using a competitive enzymelinked immunosorbent assay to detect virus antibodies in penbased oral-fluid specimens. Journal of Swine Health and Production 23: 126-131.

Tasara T, Hoelzle LE and Stephan R (2005). Development and evaluation of a Mycobacterium avium subspecies paratuberculosis (MAP) specific multiplex PCR assay. International Journal of Food Microbiology 104: 279-287.

Thurmond MC and Perez AM (2006). Modeled detection time for surveillance for foot-and-mouth disease virus in bulk tank milk. American Journal of Veterinary Research 67: 2017-2024.

U.S. Food and Drug Administration (2015). Grade 'A' Pasteurized Milk Ordinance. United States Department of Health and Human Services, Washington, D.C.

USDA (1981). Hog Cholera and its Eradication. A Review of the U.S. Experience, 91-55. United States Department of Agriculture, Animal and Plant Health Inspection Service.

USDA (2014). 2012 Census of Agriculture, Geographic Area Series, AC-12-A-51-Volume 1. United States Department of Agriculture, National Agricultural Statistics Service.

USDA (2017). Meat Animals Production, Disposition, and Income-2016 Summary, 0748-0318. United States Department of Agriculture, National Agricultural Statistics Service.

van den Brom R, van Engelen E, Luttikholt S, Moll L, van Maanen K and Vellema P (2012). Coxiella burnetii in bulk tank milk samples from dairy goat and dairy sheep farms in The Netherlands in 2008. Veterinary Record 170: 310.

van Weering $H$, van Schaik $G$, van der Meulen A, Waal M, Franken P and van Maanen K (2007). Diagnostic performance of the Pourquier ELISA for detection of antibodies against Mycobacterium avium subspecies paratuberculosis in individual milk and bulk milk samples of dairy herds. Veterinary Microbiology 125: 49-58.

Vergne T, Chen-Fu C, Li S, Cappelle J, Edwards J, Martin V, Pfeiffer DR, Fusheng G and Roger FL (2017). Pig empire under infectious threat: risk of African swine fever introduction into the People's Republic of China. Veterinary Record 181: 117.

Vincent A, Awada L, Brown I, Chen H, Claes F, Dauphin G, Donis R, Culhane M, Hamilton K, Lewis N, Mumford E, Nguyen T, Parchariyanon S, Pasick J, Pavade G, Pereda A, Peiris M, Saito $\mathrm{T}$, Swenson S, Ven Reeth K, Webby R, Wong F and Ciacci-Zanella J (2014). Review of influenza A virus in swine worldwide: a call for increased surveillance and research. Zoonoses and Public Health 61: 4-17.

Wensvoort G, Terpstra C, Pol JMA, ter Laak EA, Bloemraad M, de Kluyver EP, Kragten C, van Buiten L, den Besten A, Wagenaar F, Broekhuijsen JM, Moonen PLJM, Zetstra T, de Boer EA, Tibben H, de Jong MF, van 't Veld P, Greenland GJR, van Gennep JA, Voets M, Verheijden JHM and Braamskamp J (1991). Mystery swine disease in The Netherlands: the isolation of Lelystad virus. Veterinary Quarterly 13: $121-130$

White D, Rotolo M, Olsen C, Wang C, Prickett J, Kittawornrat A, Panyasing $\mathrm{Y}$, Main R, Rademacher $\mathrm{C}$, Hoogland $\mathrm{M}$ and Zimmerman JJ (2014). Comparison of specimens for detection of porcine reproductive and respiratory syndrome virus infection in boar studs. Journal of Swine Health and Production 22: 138-141.

Wilson DJ, Rood K, Biswas P and Byrem TM (2010). Herd-level prevalence of Johne's disease in Utah and adjacent areas of the Intermountain West as detected by a bulk-tank milk surveillance project. Journal of Dairy Science 93: 5792-5797.

Zanardi G, Caminiti A, Delle Donne G, Moroni P, Santi A, Galletti G, Tamba M, Bolzoni G and Bertocchi L (2014). Short communication: comparing real-time PCR and bacteriological cultures for Streptococcus agalactiae and Staphylococcus aureus in bulk-tank milk samples. Journal of Dairy Science 97: 5592-5598.

Zhang J (2016). Porcine deltacoronavirus: overview of infection dynamics, diagnostic methods, prevalence and genetic evolution. Virus Research 226: 71-84.

Zimmerman JJ, Benfield DA, Dee SA, Murtaugh MP, Stadejek T, Stevenson GW, and Torremorell M (2012). Porcine reproductive and respiratory syndrome virus (porcine arterivirus). In: Zimmerman JJ, Karriker LA, Ramirez A, Schwartz KJ and Stevenson GW (eds) Diseases of Swine, 10th edn. Ames: Wiley and Sons, pp. 461-486. 